\title{
Market Integration and Seasonal Price Variation of Pangas Fish in Some Selected Areas of Bangladesh
}

\author{
Md. Imran Omar ${ }^{1} \&$ Mohammad Shamsul Hoq ${ }^{1}$, Syed Ariful Haque ${ }^{2} \&$ \\ Mohammad Azharul Alam ${ }^{2}, \&$ Md. Ashraful Islam ${ }^{3}$ and Umme Aymon Jania ${ }^{4}$ \\ ${ }^{I}$ Scientific officer, Agricultural Economics Division, Bangladesh Agricultural Research Institute, Joydevpur, \\ Gazipur-1701. \\ ${ }^{2}$ Lecturer, Department of Fisheries Technology \& Department of Fisheries Biology and Genetics, Sheikh \\ Fajilatunnesa Mujib Fisheries College, Melandah, Jamalpur. \\ ${ }^{3}$ Assistant Professor, Department of Dairy and Poultry Science, Patuakhali Science and Technology University, \\ Bangladesh, \\ ${ }^{4}$ M.S Student, Department of Aquaculture, Faculty of Fisheries, Bangladesh Agricultural University, \\ Mymensingh-2200.
}

\begin{abstract}
A study was undertaken to examine the marketing system and price behavior of Pangas fish in selected areas of Mymensingh district of Bangladesh during the month of June-October 2012. The objectives of the study were to estimate costs and margins, seasonal price variation and to test market integration of Pangas fish. Primary and secondary data were used for this study. The higher marketing cost was incurred by aratdars and the lowest by retailer. On the other hand, retailers earned the highest net marketing margins. Analysis of market integration shows that Pangas fish market in Bangladesh was well integrated. The study identified some problems related to economic, technical, marketing, social and natural calamities aspects and suggested some measures for solving these problems. The findings of the study revealed that the marketing of Pangas was a profitable business and some recommendations were provided for the improvement of Pangas marketing in the country.
\end{abstract}

Keywords: Market integration, Engle Granger co-integration, Price behavior, Pangas,

\section{Introduction}

Bangladesh is considered one of the most suitable countries in the world for freshwater aquaculture, because of its favorable resources and agro-climatic conditions. A sub-tropical climate, vast areas of pond, lowlying agricultural land and seasonal semi-closed shallow water provide ideal conditions for fish production. The freshwater inland aquaculture production in Bangladesh is the second highest in the world after China (FAO, 2009). The total annual fish production was estimated to be 2.56 million tons in 2007-08 (Bangladesh fiscal year: 1 July-30 June), of which 1.00 million tons (39\%) were obtained from inland aquaculture, 1.06 million tons $(41 \%)$ from inland capture fisheries, and 497,573 tons (20\%) from marine fisheries (DOF, 2009). The main production systems for freshwater aquaculture in Bangladesh are extensive and semi-intensive pond polyculture of Indian major carps and exotic carps which accounts for $80 \%$ of the total freshwater aquaculture production. The remaining $20 \%$ were mainly from catfish, tilapia, small indigenous fish and rice-fish farming (ADB, 2005). Consumers of this country normally used to like indigenous carps, shrimp, catfish and other small species as food fish but due to their unavailability and extremely high price in the domestic market, they are bound to purchase Pangas and Chinese carp species. The present study aimed to identify, particularly the marketing channels, institutions, functions and basic problems in the marketing of Pangas in Bangladesh. The study would make recommendation and suggestions to improve the organization and operation of Pangas fish marketing with a view to enhancing efficiency by analyzing the present marketing problems. In view of these, the survey was conducted to examine marketing and price behavior of Pangas fish in selected areas of Mymensingh district. The specific objectives of the study were to examine the existing marketing system of Pangas fish, to examine cost and margins at different stages of marketing channels, to examine the price behavior in terms of seasonal price variation, to identify the major problems of Pangas fish marketing and suggest some remedial measures. Thus the study was conducted for understanding the present situation of marketing system of Pangas fish in different regions of Bangladesh with following objectives.

\section{Objectives}

i. To examine the nature of marketing system and marketing cost, of Pangas fish marketing.

ii. To analyse the market integration of Pangas fish and 


\section{iii. To examine seasonal price variation of Pangas fish}

\section{Materials And Methods}

The present study was conducted based on field survey method wherein primary data were collected from the respondents. Secondary data was collected from journals, thesis and raw data from monthly bulletin of Directorate of Agricultural Marketing (DAM) and District Fisheries Office. In Mymensingh district there were a number of successful Pangas producers, trader's i.e.Aratdar, Bepari, Paiker and retailer etc. The study area is confined to three Upazilas namely Mymensingh Sadar,Fulpur and Tarakanda upazilas in Mymensingh district, where the cultivation of Pangas fish was concentrated. Purposive sampling techniques were used for selecting the sample. Total sample size of the study was 150 .Selected samples consisted of 40 fish farmers and 110 traders. For this study, 30 stocking ponds were selected from Tarakanda and Fulpur upazilas. The intermediaries dealing with Pangas marketing were categorized into three groups, namely, Aratdar, Paiker and retailer. From different stages of fish marketing 40 Paikers, 15Aratdars and 55 retailers were selected as respondents for the study. Among them two Aratdars and five retailers from Tarakanda, two Aratdars and five retailers from Fulpur, twelve Paikers, three Aratdars and seven retailers from Balukaand eight Paikers, three Aratdars and eight retailers from Kawran Bazar of Dhaka City were selected. The data were collected intensively by using structured interview schedules. The weekly average wholesale prices of Banana of various markets like Dhaka, Chittagong, Sylhet, Khulna, Rajshahi and Mymensingh during 1983 to 2012 were collected from Department of Agricultural Marketing (DAM). Latter it was converted into monthly figures.

\section{Analytical Techniques}

The following techniques were used for the analysis.

i. For estimating seasonal price variation ratio to moving average method was used.

ii. Determination of market integration through Engle and Granger co-integration method was used.

\section{Farmer's net prices were calculated by using following formulas:}

Farmer's net price $=$ Farmer's sale price - Farmer's marketing cost

Market Integration: The main objective of price policy is to safeguard the interests of producers and consumers. The producer's interest can best be safeguarded if he is paid appropriate price for his product. He gets fair prices if markets are well integrated. The basic idea behind the measurement of market integration is to understand the interaction among prices in spatially separated markets (Goletti and Babu, 1994, pp. 311-325). Thus integrated markets are defined as markets in which prices of differentiated products do not behave independently (Monke and Petzel, 1984, pp. 401-487).

If price movement of a commodity in one market is completely irrelevant to forecast price movements of the same commodity in other markets, the markets are characterized as segmented (Kumar and Sharma 2003, p. 203). In well integrated markets, middlemen's share should be reasonable and consumers get produce at fair price. So it is very important to understand whether commodity markets function efficiently. Markets function efficiently when these are integrated in price relationships and it is also imperative to see whether infrastructural and technological development in communication system has improved the functioning of commodity markets.

Measurement of Market Integration by Co-integration Method: The bulk of econometric theories have been based on the assumption that the underlying data process is stationary a) stochastic process is said to be stationary if its mean and variance are constant over time and the value of covariance between two time periods depends only on the distance or gap or lag between the two time periods and not the actual time at which the covariance is computed (Gujarati, 2003, p.797). In practice, most economic time series are nonstationary.Applying regression models to non-stationary data may arise the problem of "spurious or nonsense" correlation (Gujarati, 2003, p. 792). If the time series data like prices, which are non-stationary, are used, it usually would yield a high $\mathrm{R}^{2}$ and ' $\mathrm{t}$ ' ratios which are biased towards rejecting the null hypothesis of no relationship between the variables concerned. To overcome such problems, the concept of co-integration was used becauseit offers a means of identifying and hence avoiding the spurious.

In a high inflationary situation like Bangladesh, use of nominal price to use in estimation to correlation coefficient (pair wise) would be misleading as the force of inflation over the years for which, estimated coefficients may tend to show high degree of association between pair of prices of two markets. So, other advanced method of assessing market integration like co-integration method was also needed and that was used in this study. The underlying principle of co-integration analysis is that, although trend of many economic series show upward or downwards over time in a non-stationary fashion, group of variables may drift together.

Unit Root and Co-integrationTest: The individual price series weretested for the order of integration to determine whether they are stationary which is known as the unit root test (Gujarati, 2003, p.799). A number of 
tests for stationarity are available in the literature; these include the Dickey-Fuller (DF) test (Dickey and Fuller,1979), the Augmented Dickey-Fuller(ADF) test (Dickey and Fuller,1981)and the Philips-Perron (PP) test (Perron,1988). For theoretical and practical reasons, the Dickey-Fuller test is applied to regressions run in the following forms:

$\mathrm{Y}_{\mathrm{t}}$ is a random walk or without constant:

$$
\Delta \mathrm{Y}_{\mathrm{t}}=\delta \mathrm{Y}_{\mathrm{t}-1}+\mathrm{e}_{\mathrm{t}}
$$

$Y_{t}$ is a random walk with drift or constant:

$$
\Delta \mathrm{Y}_{\mathrm{t}}=\beta_{1}+\delta \mathrm{Y}_{\mathrm{t}-1}+\mathrm{e}_{\mathrm{t}}
$$

$\mathrm{Y}_{\mathrm{t}}$ is a random walk with drift around a stochastic trend (constant plus trend):

$$
\Delta \mathrm{Y}_{\mathrm{t}}=\beta_{1}+\beta_{2} \mathrm{t}+\delta \mathrm{Y}_{\mathrm{t}-1}+\mathrm{e}_{\mathrm{t}}
$$

Where $t$ is the time or trend variable.

In each case the null hypothesis is $\delta=0(\rho=1)$; that is, there is a unit root, that means the time series is nonstationary. The alternative hypothesis is that $\delta$ is less than zero; that is, the time series is stationary. Under the null hypothesis, the conventionally computed $t$ statistics is known as the $\tau$ (tau) statistic, whose critical values have been tabulated by Dickey and Fuller. If the null hypothesis is rejected, it means that $\mathrm{Y}_{\mathrm{t}}$ is a stationary time series with zero mean in the case of $(1)$, that $Y_{t}$ is stationary with a non-zero mean $\left[=\beta_{1} /(1-\rho)\right]$ in the case of (2), and that $Y_{t}$ is a stationary around a deterministic trend in equation (3).

It is extremely important to note that the critical values of the tau test to test the hypothesis that $\delta=0$, are different for each of the preceding three specifications of the DF test. If the computed absolute value of the tau statistics $(\tau)$ exceeds the DF or MacKinnon critical tau values, we reject the hypothesis that $\delta=0$, in which case the time series is stationary. On the other hand, if the computed $(\tau)$ does not exceed the critical tau value, we do not reject the null hypothesis, were the time series is non-stationary.

In conducting the DF test as in (1), (2), or (3), it was assumed that the error term $\mathrm{e}_{\mathrm{t}}$ was uncorrelated. But in case the $e_{t}$ are correlated, Dickey and Fuller have developed a test known as the augmented Dickey-Fuller (ADF) test. This test is conducted by "augmenting" the preceding equation by adding the lagged values of the dependent variable $\Delta \mathrm{Y}_{\mathrm{t}}$. The ADF test here consists of estimating if the error term $\mathrm{e}_{\mathrm{t}}$ is auto correlated, one modifies (4) as follows:

$$
\Delta \mathrm{Y}_{\mathrm{t}}=\beta_{1}+\beta_{2} \mathrm{t}+\delta \mathrm{Y}_{\mathrm{t}-1}+\alpha_{\mathrm{i}} \sum_{\mathrm{i}=1}^{\mathrm{m}} \Delta \mathrm{Y}_{\mathrm{t}-\mathrm{i}}+\varepsilon_{\mathrm{t}}
$$

where $\varepsilon_{\mathrm{t}}$ is a pure white noise error term and where, $\Delta \mathrm{Y}_{\mathrm{t}-1}=\left(\mathrm{Y}_{\mathrm{t}-1}-\mathrm{Y}_{\mathrm{t}-2}\right), \Delta \mathrm{Y}_{\mathrm{t}-2}=\left(\mathrm{Y}_{\mathrm{t}-2}-\mathrm{Y}_{\mathrm{t}-3}\right)$, etc., that is, one uses lagged difference terms. The number of lagged difference terms to include is often determined empirically, the idea being to include enough terms so that the error term in (4) is serially uncorrelated. The null hypothesis is still that $\delta=0$ or $\rho=1$, that is, a unit root exists in Y (i.e., Y is non-stationary).

Spatial Price Relationship: To test the market integration, the following co-integration regression was run for each pair of price series:

$$
\mathrm{Y}_{\mathrm{it}}=\alpha_{0}+\alpha_{1} \mathrm{Y}_{\mathrm{jt}}+\varepsilon_{\mathrm{t}}
$$

Where, $Y_{i}$ and $Y_{j}$ are price series of a specific commodity in two markets $i$ and $j$, and $\varepsilon_{t}$ is the residual term assumed to be distributed identically and independently. The test of market integration is straightforward if $Y_{i}$ and $\mathrm{Y}_{\mathrm{j}}$ are stationary variables but if the price series proved as non-stationary then we have to done another test (Engle-Granger test)

Testing whether the variables are co-integrated is merely another unit root test on the residual in equation (5). However, since the $\mathrm{Y}_{\mathrm{i}}$ and $\mathrm{Y}_{\mathrm{j}}$ are individually non-stationary, there is the possibility that the regression is spurious. The DF and ADF tests in the present context are known as Engle-Granger (EG) test whose critical values was provided by Engle-Granger (Ramakumar, 1998). The test involved regression the first-difference of the residual lagged level and lagged dependent variables (Engle-Granger test) is as follows:

For Engle-Granger (EG) test, $\Delta \varepsilon_{\mathrm{t}}=\beta \varepsilon_{\mathrm{t}-1}$ 
If the computed value of ' $t$ ' of regression coefficient $\beta$ is higher (in absolute term) than tabulated value, our conclusion is that the residuals from the regression are I (0), that is they are stationary and the regression is not spurious even though individually two variables are non-stationary.

\section{Marketing system of Pangas fish}

\section{Results And Discussion}

From the result of the study, a complete Pangas marketing system in Mymensingh region were found, which include fish farmers, channel of Tarakanda, Fulpur, Baluka and Dhaka City.

\section{Marketing functions of Pangas fish}

In Tarakanda, fish farmers sold $87.5 \%$ of their fishes to Paikers, $12.1 \%$ to Aratdar through retailers and rest $0.4 \%$ were kept for own consumption and gift. Paikers purchased $87.5 \%$ of their fish from fish farmers and sold64.5\% of their fishes to Aratdars through Paiker at district level and the rest 35.5\% to retailers. Retailers purchased $12.1 \%$ of fish from farmer's and $35.5 \%$ to Paikers and sold the entire fish to ultimate consumer (Table 1). In Fulpur, fish farmers sold $89.7 \%$ oftheir fishes to Paikers, $9.6 \%$ to Aratdar through retailers and rest $0.7 \%$ were kept for own consumption and gift. Paikers purchased $89.7 \%$ of their fish from fish farmers and sold 78.5\% of their fishes to Aratdars through Paiker at district level and the rest $21.5 \%$ to retailers. Retailers Purchased $9.6 \%$ of fish from farmers and $21.5 \%$ to Paikers and sold the entire fish to ultimate consumer. In Baluka, Paiker procured $100 \%$ of their product from the farmers of two selected areas through the local Aratdars. They sold $100 \%$ of their products to retailers through Aratdars. Retailer sold the same to consumers. On the other hand in the Dhaka City, Paiker procured $100 \%$ from the farmers of two selected areas through the local Aratdars and they sold the entire amount to retailers through Aratdars. Retailer sold the same to consumers (Table1).

Table 1. Percentage of fish transacted by fish farmers and intermediaries in Tarakanda, Fulpur, Mymensingh Town and Dhaka City

\begin{tabular}{|c|c|c|c|c|c|c|}
\hline Region & Group & \multicolumn{2}{|c|}{ Purchased from $(\%)$} & \multicolumn{2}{|c|}{ Sold to $(\%)$} & consumers \\
\hline \multirow{3}{*}{ Tarakanda, } & Farmer & - & - & 87.5 & 12.1 & - \\
\hline & Paiker & 87.5 & - & 64.5 & 35.5 & - \\
\hline & Retailer & 12.1 & 35.5 & - & - & 100 \\
\hline Fulpur, & Retailer & 9.6 & 21.5 & - & - & 100 \\
\hline \multirow{2}{*}{ Baluka } & Paiker & 100 & - & - & 100 & - \\
\hline & Retailer & - & 100 & - & - & 100 \\
\hline Dhaka City & Paiker & 100 & - & - & 100 & - \\
\hline
\end{tabular}

\section{Pricing for Pangas}

In the study areas all intermediaries who were involved in the buying and selling of Pangas fish followed the open bargaining method for fixing the price of their products. The fish farmers enjoyed low bargaining power because of many factors such as perishes abilityof product, absence of storage facilities and immediate need for cash. The number of buyers attending the market and the volume of product offered for sale mainly determined the price at market level. Inthewholesale market, price varied with the variation of quality of and size of fish. At Arat level prices were fixed through auction. In that case, prices were determined on the basis of supply and demand.

\section{Marketing Cost and Margins of Pangas Fish Traders \\ Total Marketing Cost of all Intermediaries at Tarakanda}

Total cost of marketing of Pangas fish includes all costs incurred by different types of intermediaries standing between the fish farmers and ultimate consumers. It appears from Table 8 that the total cost of marketing at Tarakanda was Tk. 309.82 per quintal. Among at costs items, icing were the highest amounting to Tk. 57.38 (18percent), followed by personal expenses and wastage (Table 2). 


\section{Total Cost of Intermediaries at Fulpur}

Total cost of marketing Pangas fishes includes all cost incurred by different typesof intermediariesstanding between the fish farmers and the ultimate consumers. It has been seen from Table 5, that the total cost of marketing fish at Fulpur was Tk.334.78 per quintal. Among all the cost items, wastage cost was the highest amounting to 65.98 (25\%), followed by icing and personal expenses (Table 2).

Table 2. Marketing cost of intermediaries per quintal of fishes at Tarakanda\&Fulpur (Tk./quintal)

\begin{tabular}{|c|c|c|c|c|c|c|c|c|}
\hline \multirow{3}{*}{ Cost Items } & \multicolumn{4}{|c|}{ Tarakanda } & \multicolumn{4}{|c|}{ Fulpur } \\
\hline & \multicolumn{2}{|c|}{ Types Of Intermediaries } & \multirow[b]{2}{*}{ Total Cost } & \multirow[b]{2}{*}{$\%$} & \multicolumn{3}{|c|}{ Types Of Intermediaries } & \multirow[b]{2}{*}{$\%$} \\
\hline & $\operatorname{Aratdar}(T k)$. & Retailer(Tk.) & & & $\operatorname{Aratdar}(T k)$. & Retailer(Tk.) & Total Cost & \\
\hline Transportation & & $26.78(10.87)$ & 26.78 & 8.64 & & $28.32(10.58)$ & 28.32 & 8.46 \\
\hline Wages\& Salary & $26.93(40.49)$ & & 25.93 & 8.37 & $24.86(37.01)$ & & 24.86 & 7.42 \\
\hline $\begin{array}{l}\text { Personal } \\
\text { Expenses }\end{array}$ & $8.69(13.67)$ & $43.79(17.78)$ & 48.29 & 15.6 & $9.74(14.5)$ & $38.84(14.54)$ & 48.58 & 14.51 \\
\hline Licing & $4.5(7.07)$ & $48.82(19.8)$ & 57.38 & 18.5 & $5.23(7.79)$ & $56.34(21.05)$ & 61.57 & 18.39 \\
\hline Market Tolls & $5.18(8.15)$ & $17.86(7.25)$ & 23.04 & 7.43 & $5.8(8.63)$ & $14.12(5.28)$ & 19.92 & 5.95 \\
\hline Phone Charges & $6.90(10.85)$ & & 6.9 & 2.23 & $6.81(10.14)$ & & 6.81 & 2.03 \\
\hline Electricity & $2.36(3.7 .1)$ & $8.60(3.49)$ & 10.96 & 3.54 & $3.56(5.3)$ & $6.94(2.59)$ & 10.5 & 3.14 \\
\hline Entertainment & $8.56(13.47)$ & & 8.69 & 2.80 & $9.54(14.2)$ & & 9.54 & 2.85 \\
\hline Basket & & $18.34(7.44)$ & 18.34 & 5.92 & & $17.85(6.68)$ & 17.85 & 5.33 \\
\hline Packing \& & & $16.56(6.72)$ & 16.56 & 5.34 & & $16.64(6.12)$ & 16.64 & 4.97 \\
\hline Materials & & & & & & & & \\
\hline Wastage & & $36.58(14.85)$ & 36.58 & 11.8 & & $65.98(25.06)$ & 65.98 & 19.70 \\
\hline Cleaning & $0.63(0.99)$ & $28.95(11.75)$ & 29.56 & 9.54 & $0.85(1.26)$ & $22.52(7.85)$ & 23.43 & 6.99 \\
\hline Total & $63.56(100)$ & $248.20(100)$ & 308.85 & 100 & $67.17(100)$ & $267.61(100)$ & 333.25 & 100 \\
\hline
\end{tabular}

Total Marketing Cost of all Intermediaries at Baluka

Total cost of marketing for all intermediaries in Baluka was estimated to be Tk. 673.1 per quintal (Table 3). Among all the cost items, Aratdar's commission was the highest amounting to Tk. 198.9 (29\%).

Table 3. Marketing cost of intermediaries per quintal of fishes at Baluka \& Dhaka City (Tk./quintal)

\begin{tabular}{|c|c|c|c|c|c|}
\hline \multirow{2}{*}{ Cost Item } & \multicolumn{5}{|c|}{ Types of Intermediaries } \\
\hline & Paiker & Arathdar & Retailer & Total Cost & Percentage \\
\hline Transportation & $44.12(12.1)$ & & $18.52(7.78)$ & 62.64 & 9.30 \\
\hline ArathdarCommision & $198.99(54.57)$ & & & 198.99 & 29.56 \\
\hline Wages\& Salary & $31.84(8.73)$ & $28.32(40.25)$ & & 60.16 & 8.94 \\
\hline Wastage & $15.53(2.26)$ & & $40.56(17)$ & 56.09 & 8.33 \\
\hline Personal Expenses & $22.50(6.17)$ & $9.63(13.68)$ & $36.72(15.42)$ & 68.85 & 10.23 \\
\hline Licing & & $5.5(7.82)$ & $42.67(17.92)$ & 48.17 & 7.16 \\
\hline Phone Charges & $18.50(5.07)$ & $7.6(10.80)$ & & 26.1 & 3.88 \\
\hline Loding\&Unloding & $21.56(5.91)$ & & & 21.56 & 3.20 \\
\hline Electricity & & $5.56(7.9)$ & $5.56(2.33)$ & 11.12 & 1.65 \\
\hline Market Tolls & & $12.83(18.23)$ & $33.41(14.03)$ & 46.24 & 6.87 \\
\hline Packing \& Materials & $11.56(3.18)$ & & $38.56(16.2)$ & 50.14 & 7.45 \\
\hline Cleaning & & $0.92(1.23)$ & $22.14(9.3)$ & 24.14 & 3.42 \\
\hline Total & $364.61(100)$ & $70.36(100)$ & $238.1(100)$ & 703.14 & 100 \\
\hline
\end{tabular}

\section{Total Marketing Cost of all Intermediaries in Dhaka City}

The total marketing cost of all intermediaries in Dhaka city was estimated to be Tk. 1284.9 per quintal (Table 4) which was very high compared to other selected areas. In Dhaka, Aratdar's commission was found the highest cost comprising nearly one third of the total cost. The other cost items in descending order were transportation $(27 \%)$, wages and salary $(8 \%)$, personal expenses $(7 \%)$, electricity $(5 \%)$, packaging materials $(4 \%)$, icing $(4 \%)$, wastage $(3 \%)$, market toll (3\%), rent $(2 \%)$, watering $(2 \%)$, entertainment $(2 \%)$, loading and unloading $(2 \%)$, tips and donation $(1 \%)$ and telephone charge $(1 \%)$. 
Table 4. Marketing cost of intermediaries per quintal of fishes in Dhaka City (Tk./quintal) Marketing Margin of Intermediaries

\begin{tabular}{|c|c|c|c|c|c|}
\hline \multirow[t]{2}{*}{ Cost Item } & \multicolumn{5}{|c|}{ Types of Intermediaries } \\
\hline & Paiker & Arathdar & Retailer & Total Cost & Percentage \\
\hline ArathdarCommision & $400(49.75)$ & & & 400 & 31.31 \\
\hline Transportation & $288.83(35.55)$ & & $58.36(15.57)$ & 347.19 & 27.09 \\
\hline Wages\& Salary & $54.26(6.75)$ & $45.95(43.23)$ & & 100.2 & 7.789 \\
\hline Wastage & $17.38(2.16)$ & & $25.32(6.76)$ & 42.7 & 3.32 \\
\hline Licing & & $7.87(7.4)$ & $40.28(10.75)$ & 48.15 & 3.75 \\
\hline Entertainment & & $6.98(6.57)$ & & 25.58 & 1.99 \\
\hline Personal Expenses & $5.72(0.71)$ & $25.58(24.07)$ & $76.84(20.5)$ & 89.54 & 6.97 \\
\hline Market Tolls & & $12.28(11.56)$ & $28.76(7.68)$ & 41.04 & 3.19 \\
\hline Phone Charges & $4.80(0.59)$ & $4.20(3.95)$ & & 9 & 0.70 \\
\hline Loding\&Unloding & $17.44(3.4)$ & & & 20.70 & 1.61 \\
\hline Tips and Donation & & $1.8(1.69)$ & $12.69(3.39)$ & 14.49 & 1.13 \\
\hline Electricity & & $1.58(1.48)$ & $40.56(10.82)$ & 59.94 & 4.66 \\
\hline Packing \& Materials & $15.58(1.94)$ & & $34.56(9.22)$ & 50.14 & 3.9 \\
\hline Watering & & & $27.11(7.23)$ & 27.11 & 2.1 \\
\hline Rent & & & $30.22(8.02)$ & 30.22 & 2.35 \\
\hline Total & $804.01(100)$ & $106.23(100)$ & $374.7(100)$ & 12.84 .94 & 100 \\
\hline
\end{tabular}

\section{Marketing Margin of Intermediaris}

In the study area, Aratdar's did not perform buying and selling function. They sold the product on behalf of fish farmers for which they received commission (Tk.2 kg-1) that considered as income. Aratdar's net margin or profit was estimated at Tk. 136.4 per quintal of fishes. Because the marketing cost of Aratdar was Tk. 63.56 per quintal and the profit was calculated by deducting the marketing cost from gross margin or commission received. The marketing margin of retailers at Tarakanda is shown in Table 5. The retailers who purchased fish from Aratdar's and sold to consumers earned a gross margin of Tk. 1091.6 per quintal and after deducting marketing cost of Tk. 309.8 per quintal, the net margin earned by them was Tk. 781.8 per quintal.

Table 5. Marketing cost and Marketing Margin of Various intermediaries in Mymensingh and Dhaka City (Tk./quintal)

\begin{tabular}{|c|c|c|c|c|c|c|}
\hline Area & Intermediaries & Purchase Price & Sale Price & Gross Margin & Marketing Cost & Net Margin \\
\hline \multirow{2}{*}{ Tarakanda } & Aratdar & - & - & 200 & 63.56 & 136.44 \\
\hline & Retailer & 6075 & 7166.66 & 1091.66 & 909.82 & 781.84 \\
\hline \multirow{2}{*}{ Fulpur } & Aratdar & - & - & 200 & 67.17 & 132.83 \\
\hline & Retailer & 5966.66 & 6750 & 783.34 & 267.61 & 515.73 \\
\hline \multirow{3}{*}{ Baluka } & Paiker & 5750 & 6633.33 & 883.33 & 364.61 & 518.72 \\
\hline & Aratdar & - & - & 198.99 & 70.36 & 128.63 \\
\hline & Retailer & 6933 & 7750 & 816.67 & 238.1 & 578.57 \\
\hline \multirow{3}{*}{ Dhaka City } & Paiker & 5966.66 & 7233.33 & 1266.67 & 804.01 & 462.66 \\
\hline & Aratdar & - & - & 400 & 106.23 & 293.77 \\
\hline & Retailer & 7622.66 & 8866.66 & 1244 & 374.7 & 869.3 \\
\hline
\end{tabular}

Seasonal price variation of Pangas fish in Mymensingh and Dhaka market

The monthly wholesale price indices of Pangas for Mymensingh and Dhaka market have been presented in Table 6. It is evident from Table that the price index of Pangas was the highest (105.3) in June and the lowest (94.55) in December. The important feature of Pangas fish prices was more or less same during November to February. This implies that during this period the supply matched the demand for Pangas fish. After slight increasing in the March it continue up to the month of the June. The difference between highest and lowest indices was 10.83. The co-efficient of variation of monthly price indices of Pangas in Mymensingh market of that period was 4.09. In the Dhaka market the highest price index was 102.126 in the month of July and the lowest price index of 96.17 in the month of October. Price of Pangas fluctuated in different months. The cause of this fluctuation might be due to the change in demand or other political instability in different months. The co-efficient of variation of monthly price indices of Pangas in Dhaka market of that period was 2.11. 
Table 6. Seasonal price variation of Pangas fish indifferent markets

\begin{tabular}{lc|c}
\hline Month & Seasonal indices in Mymensingh & Seasonal indices in Dhaka \\
\hline January & 95.8 & 100.9 \\
February & 96.38 & 100.35 \\
March & 98.38 & 101.26 \\
April & 99.08 & 102.02 \\
May & 101.39 & 102.03 \\
June & 105.38 & 101.09 \\
July & 104.94 & 102.13 \\
August & 105.23 & 100.85 \\
September & 103.79 & 98.41 \\
October & 99.83 & 96.17 \\
November & 95.22 & 97.46 \\
December & 94.55 & 97.11 \\
\hline Highest & 105.38 & 102.13 \\
Lowest & 94.55 & 96.17 \\
Range & 10.83 & 5.95 \\
C.V. & 4.09 & 2.11 \\
\hline
\end{tabular}

In some of the months of the year the price declined due to the more supply of fish. In the winter season most of the fishes were harvested due to the lack of water and market become saturated with fishes. Due to higher supply and lower demand fishes, the prices of fish become lower. On the other hand because of lower production, the price of fish was the highest in June. Another reason of higher price prevailed in the monthsof April to July was that the demand remained higher in those months. Sometimes, availability of substitute products of fish like Pangas fish, meat etc. was responsible for fluctuation of price of fish. Many religious festivals such as Ramadan, Eid-ul-Azha decreases the demand for fish and price fluctuation was found.

\section{Spatial Price Relationship \\ Market Integration}

The degree of interrelationships between price movements in two markets is called market integration. In other words, in an integrated market, price of a homogeneous commodity at different spatially separated locations should tend to move together indicating efficient spread of price information and inter-linkages of markets. In interlinked commodity market price movement in one location should be highly correlated with price movement in other locations.

\section{Integration by Co-integration Method}

To avoid the problem of spurious correlation between time series variables especially price variable, co-integration method was used which was developed by Engle and Granger (1987) for making firm decisions on market integration. The valuable contribution of the concepts of unit root, co-integration, is to force to find out if the regression residual are stationary (Gujarati, 2004, p. 822). As Granger (1987), notes, "A test for cointegration can be thought of as a pre-test to avoid spurious regression situations."

An intuitive explanation of the main concepts of co-integration analysis is that prices move from time to time, and their margins are subject to various shocks that drive them apart or not. If in the long run they exhibit a linear constant relation, it can be said that they are co-integrated. Granger representation theorem (Engle and Granger, 1987) tests that if a set of variables are co-integrated or integrated of order 1, denoted by I (1), there exists a valid error correction representation of the data. Converse of this theorem also holds, i.e., if an error correction model (ECM) provides an adequate representation of the variables, they must be co-integrated. The rationale behind the error correction model is that economic variables often exhibit long run equilibrium while retaining disequilibrium in the short-run. However a proportion of disequilibrium in one period can be corrected in the next period. For instance, price changes in one period may depend upon surplus demand of the previous period. Hence it is possible to recognize the short-run and long-run behavior through an error correction mechanism. The detail method is as follows:

\section{Co-integration Test for Pangas Fish}

To test the stationary of the prices of Pangas Fish, the DF and ADF tests for wholesale price of Pangas fish were conducted. ADF test was applied in case where serial correlation exists and that could be found from 
the Durbin Watson statistic (d-value). The estimated tau $(\tau)$ statistic of the regression coefficient of one period lagged price, DW statistic and decision that was undertaken are presented in Table 7.

The tau $(\tau)$ statistic compared with absolute values (e.g., estimated t values 1.256, -1.971 and -1.828for Dhaka district prices which are less than the critical $\tau$ values without a constant, with a constant and with a constant and trend $(-2.60,-3.51$ and -4.04 at $1 \%$ level). That means the null hypothesis is accepted and concluded that the Pangas fish prices of Dhaka district contained unit root that is the price series is non-stationary. Similarly, it is found that prices of Pangas fish of all the selected districts are non-stationary.

The next step is to examine whether bivariate co-integration exists among different districts Pangas fish prices. The researcher's aim was to find that which market's price influences others. It is normally assume that Dhaka is the reference market and it influences other markets prices. As data on prices of Pangas fish for Dhaka, Chittagong, Rajshahi, Khulna, Sylhet, Mymensingh and Gazipur was available from DAM's weekly price report from the year of 2000 to 2012, so the available data were used for the analysis. In Table 8.the results of estimated co-integration regression and the final result were presented. The Engle-Granger (EG) tests of residual or error term confirmed the stationary of the residual series for all groups of two markets.

Thus the results indicated that the residual series (which are linear combination of Pangas fish price series) are stationary at level I (0). That means yet the original price series being non-stationary but their linear combination being I (0), the series are co-integrate

Table 8: Unit Root Test (Test of Stationarity/Non-stationarity) for the Prices of Pangas fish

\begin{tabular}{|c|c|c|c|c|c|c|c|c|c|}
\hline $\begin{array}{c}\text { Marke } \\
\mathbf{t}\end{array}$ & $\begin{array}{c}\text { Metho } \\
\text { d }\end{array}$ & Condition & $\begin{array}{c}\text { Intercep } \\
\mathbf{t}\end{array}$ & $\begin{array}{l}\text { Coefficient } \\
\text { of }\end{array}$ & $\begin{array}{c}\text { Coefficient } \\
\text { of }\end{array}$ & $\begin{array}{l}\text { Coefficient } \\
\text { of }\end{array}$ & $\begin{array}{c}\text { Coefficient of } \\
\text { trend }\end{array}$ & $\begin{array}{c}\text { d- } \\
\text { value }\end{array}$ & $\begin{array}{c}\text { Decisio } \\
\text { n }\end{array}$ \\
\hline \multirow{4}{*}{ 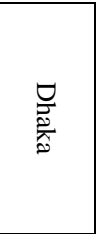 } & used & used & & Pt-1 & $\Delta \mathrm{Pt}-1$ & $\Delta \mathrm{Pt}-2$ & $(\mathrm{t})$ & & \multirow{4}{*}{ 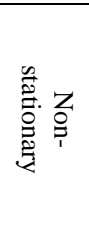 } \\
\hline & \multirow{3}{*}{ DF } & $\begin{array}{l}\text { Without } \\
\text { constant }\end{array}$ & & $\begin{array}{c}0.007 \\
(-1.256)\end{array}$ & & & & 2.12 & \\
\hline & & With constant & 27.24 & $\begin{array}{c}-0.127 \\
(-1.971)\end{array}$ & & & & 2.24 & \\
\hline & & With constant \& trend & 55.4 & $\begin{array}{c}-0.248 \\
(-1.828)\end{array}$ & & & 3.295 & 1.96 & \\
\hline \multirow{3}{*}{ 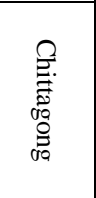 } & \multirow{3}{*}{ DF } & $\begin{array}{l}\text { Without } \\
\text { constant }\end{array}$ & & $\begin{array}{c}0.003 \\
(-1.251)\end{array}$ & & & & 1.39 & \multirow{3}{*}{ 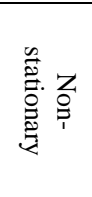 } \\
\hline & & With constant & 17.65 & $\begin{array}{c}-0.125 \\
(-1.628)\end{array}$ & & & & 1.74 & \\
\hline & & With constant \& trend & 39.4 & $\begin{array}{c}-0.321 \\
(-2.397)\end{array}$ & & & 2.298 & 2.06 & \\
\hline \multirow{4}{*}{ 졸 } & \multirow{3}{*}{ DF } & $\begin{array}{l}\text { Without } \\
\text { constant }\end{array}$ & & $\begin{array}{c}0.004 \\
(-0.868) \\
\end{array}$ & & & & 2.1 & \multirow{3}{*}{ 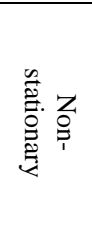 } \\
\hline & & With constant & 13.78 & $\begin{array}{c}-0.176 \\
(-1.958)\end{array}$ & & & & 1.95 & \\
\hline & & With constant \& trend & 28.008 & $\begin{array}{c}-0.374 \\
(-2.214)\end{array}$ & & & 4.981 & 1.81 & \\
\hline & $\mathrm{ADF}$ & $\begin{array}{l}1 \text { lagged difference with } \\
\text { trend }\end{array}$ & 67.05 & $\begin{array}{c}-0.58 \\
(-2.417)\end{array}$ & 0.239 & & 6.597 & 1.98 & \multirow{4}{*}{ 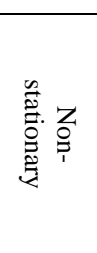 } \\
\hline \multirow{3}{*}{ 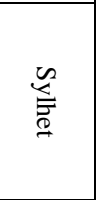 } & \multirow{3}{*}{ DF } & $\begin{array}{l}\text { Without } \\
\text { constant }\end{array}$ & & $\begin{array}{c}0.006 \\
(-1.267)\end{array}$ & & & & 2.12 & \\
\hline & & With constant & 38.24 & $\begin{array}{l}-0.137 \\
(-1.89) \\
\end{array}$ & & & & 1.81 & \\
\hline & & With constant \& trend & 74.36 & $\begin{array}{c}-0.248 \\
(-1.825)\end{array}$ & & & 3.239 & 1.98 & \\
\hline \multirow{3}{*}{ 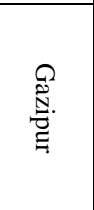 } & \multirow{3}{*}{ DF } & $\begin{array}{l}\text { Without } \\
\text { constant }\end{array}$ & & $\begin{array}{c}0.004 \\
(-0.75) \\
\end{array}$ & & & & 2.09 & \multirow{3}{*}{ 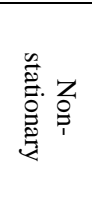 } \\
\hline & & With constant & 25.61 & $\begin{array}{c}-0.117 \\
(-1.524) \\
\end{array}$ & & & & 1.79 & \\
\hline & & With constant \& trend & 93.5 & $\begin{array}{c}-0.28 \\
(-1.789) \\
\end{array}$ & & & 4.205 & 2.01 & \\
\hline \multirow{3}{*}{ 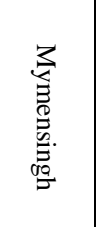 } & \multirow{3}{*}{ DF } & Withoutconstant & & 0.004 & & & & 1.87 & \multirow{3}{*}{ 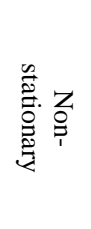 } \\
\hline & & With constant & & -1.345 & & & & 1.39 & \\
\hline & & With constant \& trend & 35.01 & $\begin{array}{l}-0.128 \\
(-1.537)\end{array}$ & & & & 2.03 & \\
\hline
\end{tabular}

Note: Figure within ( ) shows t-values of the regression coefficient.

Dickey-Fuller Critical values for $1 \%$ and $5 \%$ are: Without a constant: -2.60 and -1.95 respectively, with a constant: -3.51 and -2.89 respectively, with a constant and trend: -4.04 and -3.45 , respectively, for sample size 100 (Gujarati 2004, p.975).

Source: Department of Agricultural Marketing (DAM 2000-2012) 
Table 8. Spatial Price Relationships between different Markets for Pangas fish from May 2000 to December 2012

\begin{tabular}{|c|c|c|c|}
\hline Markets & Co-integrating Regression & $\begin{array}{c}\text { Co-integration Test } \\
\text { Engle-Granger }\end{array}$ & Decision \\
\hline Dhaka-Chittagong & $\begin{array}{l}\mathrm{P}_{\mathrm{D}}=17.316+0.869 \mathrm{P}_{\mathrm{C}} \\
\mathrm{R}^{2}=0.891 \quad \text { (32.57) }\end{array}$ & $\begin{array}{c}\Delta \mathrm{U}_{\mathrm{t}}=-0.743 \mathrm{U}_{\mathrm{t}-1} \text { *** } \\
(-8.893)\end{array}$ & Co-integrated \\
\hline Dhaka-Rajshahi & $\begin{array}{c}\mathrm{P}_{\mathrm{D}}=3.53+0.985 \mathrm{P}_{\mathrm{R}} \\
\mathrm{R}^{2}=0.892 \quad(32.664)\end{array}$ & $\begin{aligned} \Delta \mathrm{U}_{\mathrm{t}}= & -0.628 \mathrm{U}_{\mathrm{t}-1} * * * \\
& (-7.632)\end{aligned}$ & Co-integrated \\
\hline Dhaka-Khulna & $\begin{array}{c}P_{D}=16.202+0.96 P_{K} \\
R^{2}=0.895\end{array}$ & $\begin{aligned} \Delta \mathrm{U}_{\mathrm{t}}= & -0.716 \mathrm{U}_{\mathrm{t}-1} * * * \\
& (-8.581)\end{aligned}$ & Co-integrated \\
\hline Dhaka- Sylhet & $\begin{array}{c}\mathrm{P}_{\mathrm{D}}=18.93+0.87 \mathrm{P}_{\mathrm{S}} \\
\mathrm{R}^{2}=0.886\end{array}$ & $\begin{array}{c}\Delta \mathrm{U}_{\mathrm{t}}=- \\
(-7.30)\end{array}$ & Co-integrated \\
\hline Dhaka-Mymensingh & $\begin{array}{c}\mathrm{P}_{\mathrm{D}}=2.234+0.979 \mathrm{P}_{\mathrm{M}} \\
\mathrm{R}^{2}=0.884 \quad(31.413)\end{array}$ & $\begin{aligned} \Delta \mathrm{U}_{\mathrm{t}}= & -0.832 \mathrm{U}_{\mathrm{t}-1} * * * \\
& (-9.701)\end{aligned}$ & Co-integrated \\
\hline Dhaka-Gazipur & $\begin{array}{c}\mathrm{P}_{\mathrm{D}}=12.702+0.978 \mathrm{P}_{\mathrm{G}} \\
\mathrm{R}^{2}=0.801\end{array}$ & $\begin{array}{c}\Delta \mathrm{U}_{\mathrm{t}}=- \\
(-7.27)\end{array}$ & Co-integrated \\
\hline
\end{tabular}

Note: Figure within ( ) shows t-values of the regression coefficient.

Tau $(\tau)$ values (without constant) at $1 \%$ and $5 \%$ level of significance are -2.55 and -1.95 respectively in the equation.

*** indicates $1 \%$ level of significance.

** indicates $5 \%$ level of significance.

Source: Department of Agricultural Marketing (DAM 2000-2012)

As mentioned earlier, Mymensingh is surplus area in Pangas fish production and the rest districts considered in the study are deficit area, so when price changes in this surplus area then automatically prices will changes for the other districts.

Finally, the result implies that if any divergence from long-run equilibrium occurs in period $\mathrm{t}-1$, it will be adjusted towards equilibrium level in period t. Thus, the selected Pangas fish markets in Bangladesh are shown to be integrated. This is mainly attributed to close proxy, good communication facilities especially development of cell phone technology and good infrastructure availabilities among the market centers in Bangladesh.

\section{Conclusion}

The findings of this study indicated that the marketing of Pangas fish is a profitable business. Thus, the selected Pangas fish markets in Bangladesh are shown to be integrated. This is mainly attributed to close proxy, good communication facilities especially development of cell phone technology and good infrastructure availabilities among the market centers in Bangladesh. It also suggests that there is wide scope for the development of Pangas farming and trading in this country. In this study the profit of retailer was higher than that of other intermediaries. To make the business more profitable, efficient marketing system should be developed by reducing marketing cost and increasing marketing services.

\section{References}

[1]. DAM (Department of Agricultural Marketing). Wholesale price of Agricultural and Animal Products in Bangladesh(During 1998-2005),

[2]. Department of DOF (Department of Fisheries). 1999. Annual Report, Department of Fisheries, Dhaka, Bangladesh.

[3]. Engle, R. F. and Granger, C. W. J. (1987), "Co-integration and Error Correction: Representation, Estimation and Testing". Econometrica, Vol. 55 (2): 251-276.

[4]. FAO. 1997. The State of World Fisheries and Aquaculture. Food and Agriculture Organization ofthe United Nations, Rome. 125pp.

[5]. FAO. 1997. The State of World Fisheries and Aquaculture. Food and Agriculture Organization ofthe United Nations, Rome. $125 \mathrm{pp}$.

[6]. Gupta MV, Ahmed M, Ahmed M, Bimbao MA andLightfoot C. 1992. Socio-economic impact and farmers Assessment of Nile Pangas (O. niloticus) culture in Bangladesh, ICLARM technical report no.35. International Center for Living Aquatic

[7]. GOB. Government of Bangladesh (2010): Report on the Economic Survey of Bangladesh. Ministry of Finance, Ministry of Planning, Government of the Peoples Republic of Bangladesh, Dhaka.

[8]. Growth and production performance of red Pangas (Oreochromisniloticus Lin.) under low-input culturesystem. Bangladesh J. Fish. Res., 3(1): 11

[9]. Gujarati, D.N. 2003, Basic Econometrics, Fourth Edition, Tata McGraw-Hill Edition, India.

[10]. Resources Management, Manila, Philippines. 55pp.Kohinoor AHM, Modak PC and Hussain MG. 1999. 